\title{
Taxonomic novelties in Scapania
}

\author{
Jiř́ Váňa', Jörn Hentschel², Jochen Müller², Jochen Heinrichs ${ }^{3}$
}

I Department of Botany, Charles University, Benátská 2, 12801 Praha 2, Czech Republic 2 Department of Systematic Botany with Herbarium Haussknecht and Botanical Garden, Friedrich Schiller University, Fürstengraben 1, 07743 Jena, Germany 3 Department of Systematic Botany, Albrecht von Haller Institute of Plant Sciences, Georg August University, Untere Karspüle 2, 37073 Göttingen, Germany

Corresponding author: Jochen Heinrichs (jheinri@uni-goettingen.de)

Academic editor: M. von Konrat | Received 11 January 2012 | Accepted 7 March 2012 | Published 12 March 2012

Citation: Váňa J, Hentschel J, Müller J, Heinrichs J (2012) Taxonomic novelties in Scapania. PhytoKeys 10: 13-17. doi: $10.3897 /$ phytokeys. 10.2654

\section{Abstract}

Five new supraspecific taxa of Scapania are proposed, S. subg. Gracilidae, S. subg. Pseudomacrodiplophyllum, S. sect. Americanae, S. sect. Hyperboreae, and S. sect. Simmonsia.

\section{Keywords}

Scapaniaceae, nomenclature

\section{Introduction}

The northern temperate leafy liverwort genus Scapania (Dumort.) Dumort. was the subject of two comprehensive molecular phylogenetic studies (Vilnet et al. 2010, Heinrichs et al. 2012). These studies provided evidence for incongruence of the present supraspecific classification (Potemkin 2002) with the molecular tree topologies. Extensive morphological homoplasy hampers a morphological circumscription of several Scapania lineages identified in the molecular studies; however, several new combinations and taxa are needed to arrive at a monophyletic supraspecific classification (Fig. 1). In the following, the new taxa are introduced. 


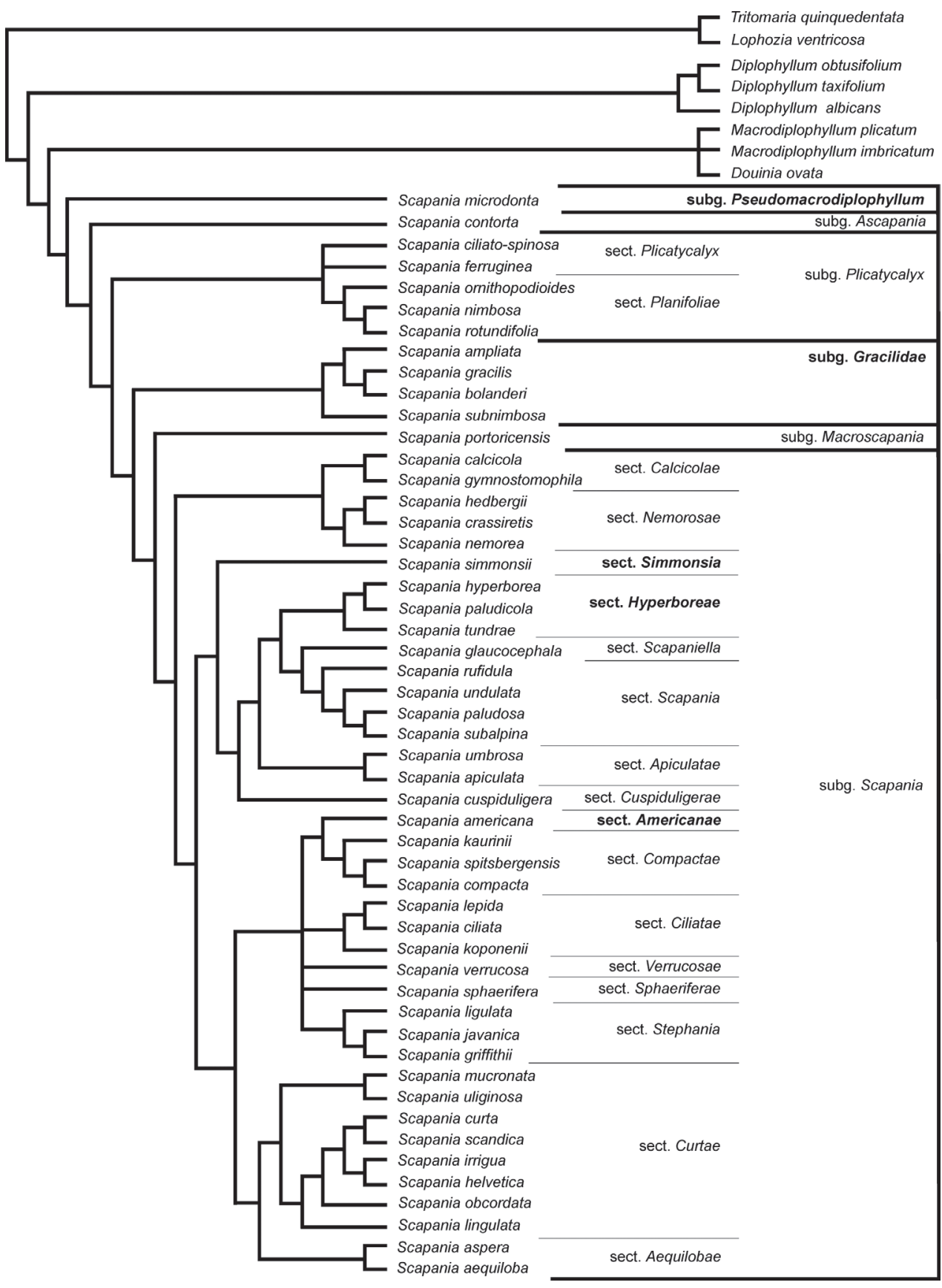

Figure I. Phylogeny of Scapania with the new taxa indicated in bold. Modified from Heinrichs et al. (2012, Fig. 1). 


\section{Taxonomy}

Scapania subg. Gracilidae (H. Buch) Váňa, Hentschel, Joch. Müll. \& Heinrichs, comb. et stat. nov.

Basionym. Scapania sect. Gracilidae H. Buch, Commentat. Biol. 3(1): 106. 1928.

Type. Scapania gracilis Lindb., Morgonbladet (Helsinki) 1873(286): 2.1873.

Note. According to the molecular phylogenies presented by Heinrichs et al. (2012), Scapania sect. Gracilidae forms a lineage outside S. subg. Scapania; hence, we propose subgenus rank (Fig. 1).

Scapania subg. Pseudomacrodiplophyllum Váňa, Hentschel, Joch. Müll. \& Heinrichs, subg. nov.

Diagnosis. Scapania subg. Pseudomacrodiplophyllum includes species which differ from other Scapania elements by the presence of multicellular gemmae with intersecting walls, basal leaf cell walls with intermediate thickenings and pluriplicate perianths.

Type. Scapania microdonta (Mitt.) Müll. Frib., Nova Acta Acad. Caes. Leop.Carol. German. Nat. Cur. 83: 262. 1905.

Note. Scapania microdonta [Macrodiplophyllum microdontum (Mitt.) Perss.] forms the sister clade to the rest of Scapania (Vilnet et al.2010, Heinrichs et al. 2012); hence, a new subgenus is introduced here to accommodate this species (Fig. 1).

Scapania sect. Americanae Váňa, Hentschel, Joch. Müll. \& Heinrichs, sect. nov.

Diagnosis. The new section of Scapania subg. Scapania is characterized by its type, the dioicous Scapania americana Müll. Frib. Distinctive features of S. americana and $S$. sect. Americanae are thick-walled, pigmented stem epidermis cells with thinnerwalled cells on the ventral side of the stem, closely and sharply ciliate-dentate leaf-margins, with largest teeth up to five cells long and terminal cells considerably longer than wide, leaf-lobes that are usually decurrent beyond the level of the keel, a verruculose or striate-verruculose cuticle, and two-celled gemmae at the margins of unmodified leaves. The dorsal leaf-lobes often develop an undulate or folded base and may even show minute lobules or auricles.

Type. Scapania americana Müll. Frib., Bull. Herb. Boissier, sér. 2, 3: 44. 1902.

Note. Scapania americana is placed sister to $S$. sect. Compactae (Müll. Frib.) H. Buch with weak bootstrap support (Heinrichs et al., 2012). It differs from members of $S$. sect. Compactae by its dioicous condition; hence we place it in a new section rather than in sect. Compactae. In our current circumscription, S. sect. Americanae is mono- 
specific, however, extension of the taxon sampling in forthcoming molecular studies may disclose further representatives.

Scapania sect. Hyperboreae Váňa, Hentschel, Joch. Müll. \& Heinrichs, sect. nov.

Diagnosis. Species of Scapania sect. Hyperboreae resemble members of Scapania sect. Curtae (Müll. Frib.) H. Buch but differ by the presence of brownish to reddish gemmae, and a usually larger size.

Type. Scapania hyperborea Jørg., Förh. Vidensk.-Selsk. Kristiania 1894(8): 56. 1894.

Note. The presence of the type species of $S$. sect. Irriguae (Müll. Frib.) H. Buch, $S$. irrigua (Nees) Nees, in $S$. sect. Curtae necessitates the introduction of a new section for the remaining elements of $S$. sect. Irriguae. Molecular data so far supported the presence of S. paludicola Loeske \& Müll. Frib. and S. tundrae (Arnell) H. Buch in S. subg. Scapania sect. Hyperboreae, as well as S. hyperborea (Vilnet et al., 2010; Heinrichs et al., 2012).

Scapania sect. Simmonsia (R.M. Schust.) Váňa, Hentschel, Joch. Müll. \& Heinrichs, comb. et stat. nov.

Basionym. Scapania subsect. Simmonsia ["Simmonsiae"] R.M. Schust., Hepat. Anthocerotae N. Amer. 3: 612. 1974.

Type. Scapania simmonsii Bryhn \& Kaal., Rep. Second Norweg. Arctic Exped. Fram 2 (11): 51. 1906.

Note. Scapania simmonsii forms an isolated lineage within S. subg. Scapania, hence, we erect a section for this species rather than using subsectional rank (Schuster, 1974). Distinctive features of the monotypic section are the deflexed-involute, broad, concave ventral leaf lobes that stand away from the stem at almost right angles and leaf cell walls with very large, nodulose trigones.

\section{Acknowledgements}

We thank Prof. em. Dr. Gerhard Wagenitz (Göttingen), Dr. David Long and Dr. John McNeill (Edinburgh) for helpful discussions. Financial support of the Deutsche Forschungsgemeinschaft (grant HE 3584/4) is gratefully acknowledged.

\section{References}

Buch H (1928) Die Scapanien Nordeuropas und Sibiriens - 2. Systematischer Teil. Commentationes Biologicae 3(1): 1-177. 
Heinrichs J, Bombosch A, Feldberg K, Kreier HP, Hentschel J, Eckstein J, Long D, Zhu RL, Schäfer-Verwimp A, Schmidt AR, Shaw B, Shaw AJ, Váňa J (2012) A phylogeny of the northern temperate leafy liverwort genus Scapania (Scapaniaceae, Jungermanniales). Molecular Phylogenetics and Evolution 62: 973-985. doi: 10.1016/j.ympev.2011.11.029

Potemkin AD (2002) Phylogenetic system and classification of the family Scapaniaceae Mig. emend. Potemkin (Hepaticae). Annales Botanici Fennici 39(4): 309-334.

Schuster RM (1974) The Hepaticae and Anthocerotae of North America. Columbia University Press, New York.

Vilnet AA, Konstantinova NA, Troitsky AV (2010) Molecular insight on phylogeny and systematics of Lophoziaceae, Scapaniaceae, Gymnomitriaceae and Jungermanniaceae. Arctoa 19: $31-50$. 